\title{
Parotid gland tissue is able partially to assume pituitary functions under the influence of hypothalamic factors: in vivo and in vitro studies
}

\author{
J A F Tresguerres, C Ariznavarreta, B Granados, P Alvarez-Vega, \\ P Fernandez-Mateos, P Gil-Loyzaga and R Alvarez-Buylla ${ }^{\mathbf{1}}$ \\ Department of Physiology Medical School and Centre of Cell Culture (CAI), Complutense University, Madrid, Spain \\ ${ }^{1}$ CUIB, University of Colima, Colima, Mexico \\ (Requests for offprints should be addressed to J A F Tresguerres)
}

\begin{abstract}
To test whether salivary tissue can secrete pituitary hormones, female Sprague-Dawley rats were hypophysectomized (hypox) and the following were transplanted to the sella turcica: parotid gland (group 3, $n=33$ ), adrenal gland (group 4, $n=30$ ), muscle (group 5, $n=24$ ). Group $2(n=21)$ had the sella turcica filled with dentist's cement. In addition a group of rats (group 1, $n=22$ ) remained intact as controls. All groups were followed for 8 months. Daily vaginal smears showed normal cyclicity in controls and constant dioestrus in all hypox groups. Blood samples, taken once every 30 days before and after LHRH stimulation, showed significantly lower $(P<0 \cdot 001)$ plasma LH values in all hypox groups compared with controls. In group 3 , a gradual and significant increase $(P<0.05)$ was observed in the LH response to LHRH in parallel with a partial recovery of oestrous smears. No LH modification was observed in the other hypox groups. Plasma prolactin (PRL) levels were also very low in all hypox groups and were unaltered throughout the study. At the end of the experiments, half the animals were killed by decapitation and the hypothalamic-pituitary areas carefully dissected, homogenized and analysed for LH and PRL content. The remaining animals were perfused with $4 \%$ paraformaldehyde to obtain fixing of the whole body tissues. Hypothalamic and transplant areas were carefully
\end{abstract}

dissected, frozen, cut and submitted to immunochemical procedures. $\mathrm{LH}$ content in the graft of group 3 animals was markedly $(P<0 \cdot 001)$ lower than in the control pituitary, but significantly higher $(P<0.05)$ than in the other hypox groups. Immunochemistry showed LH and PRL positive cells in the graft of group 3 animals, whereas neither positive cells, nor LH content were observed in the parotid gland in situ. Experiments were completed with in vitro cultures of parotid glands in the presence or absence (controls) of synthetic hypothalamic hormones or rat hypothalamic extracts. After 1.5 weeks of culture, a significantly higher LH concentration $(P<0 \cdot 05)$ was observed in the wells treated with synthetic hypothalamic hormones $(216 \pm 46 \mathrm{pg} / \mathrm{ml}$ vs $41 \pm 6 \mathrm{pg} / \mathrm{ml}$ in controls). When hypothalamic extracts were used, the LH levels increased more markedly $(1834 \pm 190 \mathrm{pg} / \mathrm{ml}$ vs $36 \pm 6 \mathrm{pg} / \mathrm{ml}$ in controls) and those values were maintained during 3 weeks of culture. Immunostaining of these cultures showed a positive $\mathrm{LH}$ reaction in the epithelial cells found in the hypothalamic extract-treated wells. Both in vivo and in vitro studies confirm the transdifferentiation of parotid gland tissue to pituitary hormone-producing cells under hypothalamic influence.

Journal of Endocrinology (1999) 160, 205-216

\section{Introduction}

Early work by Alvarez-Buylla \& Alvarez-Buylla (1963) showed, for the first time, that the autotransplant of parotid tissue to the sella turcica of young dogs after hypophysectomy led to a partial recovery of the pituitary functions when measured by indirect methods. The dogs showed longer survival time than those hypophysectomized with no transplant (Alvarez-Buylla et al. 1970a) or transplanted with muscle (Alvarez-Buylla \& Alvarez-Buylla 1964) instead of parotid gland, and this was apparently due to a certain degree of maintenance of adrenal function (Alvarez-Buylla \& Alvarez-Buylla 1970). These studies were later confirmed by measuring plasma cortisol by the competitive protein binding technique (Alvarez-Buylla \& Tsutsumi 1979).

Autotransplanted animals also showed a certain degree of recovery of thyroid function when compared with hypophysectomized and non-transplanted animals (Alvarez-Buylla et al. 1970b). Female animals showed periods of oestrus and, after mating with intact dogs, became pregnant and delivered normal pups 
(Alvarez-Buylla et al. 1973), but were unable to lactate (R Alvarez-Buylla, unpublished observation).

Although Alvarez-Buylla postulated that the transplanted salivary tissue transdifferentiated and assumed some of the properties of the pituitary cells, he was unable to demonstrate this fact to the scientific community, despite some histological studies showing structural modifications of the transplanted tissue (Alvarez-Buylla \& Tsutsumi 1979). Neither direct measurements of the pituitary hormones in plasma or in the transplanted tissue, nor immunohistochemical studies in the latter, were carried out.

Our primary aim was to reproduce the studies of Alvarez-Buylla in rats, measuring plasma and tissue contents of pituitary hormones and trying to correlate these results with immunohistochemical studies in the transplanted tissues, in order to confirm the presence and distribution of the pituitary hormones. Furthermore, primary parotid gland tissue cultures were grown and were submitted in vitro to the influence of hypothalamic extracts to unequivocally demonstrate the existence of a morphofunctional change in the salivary tissue.

\section{Materials and Methods}

The studies were performed in accordance with the principles and procedures outlined in the NIH Guide for the Care and Use of Laboratory Animals.

\section{General conditions}

One hundred and twenty eight female Sprague-Dawley rats (from Zivic Miller Laboratories Inc., Zelienople, PA, USA) weighing $150 \pm 2 \cdot 3 \mathrm{~g}$ were used. One hundred and eight were hypophysectomized (hypox) by the parapharyngeal route under microscopical control, using the method described by Alvarez-Buylla (1970). The gland was aspirated and trapped with a nylon net placed in the aspiration tube, examined under stereoscopic microscopy to assess its integrity, and fixed in a $4 \%$ paraformaldehyde solution in $0.1 \mathrm{M}$ phosphate buffer $(\mathrm{pH} 7 \cdot 3)$ for histologi$\mathrm{cal}$ and histochemical examination.

During the operation, a piece of tissue twice the size of the pituitary was obtained from the pectoral muscle, the parotid gland or the adrenal cortical gland, depending on the experimental group, taking care not to include any connective tissue. The tissue was transplanted to the sella turcica in close contact with the hypothalamic stalk, previously exposed by opening the pituitary tent. A piece of silastic (Corning Inc., Corning, NY, USA) was always used to plug the hole opened in the floor of the sella turcica, to prevent the revascularization of the graft with systemic blood vessels coming from the bone or other contiguous areas. Only blood coming from the hypothalamus was allowed to reach the graft.
Animals were divided into 5 groups: group $1(n=22)$ consisted of age- and sex-matched unoperated rats that served as controls. Group $2(n=21)$ : the pituitary was removed and the empty sella turcica was filled with dentist's cement. In the remaining three groups the pituitary was substituted with a piece of parotid gland (group 3, $n=33$ ), adrenal gland (group $4, n=30$ ) or muscle (group 5, $n=24$ ).

Rats were housed 4 per macrolon cage and maintained under controlled conditions of light $(12 \mathrm{~h}$ light $/ 12 \mathrm{~h}$ darkness), temperature $\left(21 \pm 2{ }^{\circ} \mathrm{C}\right)$ and with tap water and food (rat chow, Panlab, Barcelona, Spain) available ad libitum. The stage of the oestrous cycle was detected by daily vaginal smears. Luteinizing hormone (LH) and prolactin (PRL) plasma levels were measured at monthly intervals. At the end of the experiment, half the animals were killed by decapitation and the hypothalamicpituitary (or transplant) areas carefully dissected, homogenized in saline and kept frozen at $-80{ }^{\circ} \mathrm{C}$. One half of the in situ parotid gland of the control group was also processed. The remaining animals were perfused through the ascending aorta with 4\% paraformaldehyde in phosphate buffer $(0 \cdot 1 \mathrm{M}, \mathrm{pH} 7 \cdot 3)$ under deep general anaesthesia $(1 \mathrm{ml}(300 \mathrm{mg} / \mathrm{kg}) 10 \%$ chloralhydrate i.p.) to obtain fixing of whole body tissues. Hypothalamic and transplant (the pituitary in the controls) areas were carefully dissected and post fixed in the same solution for $3 \mathrm{~h}$. They were immersed in a $20 \%$ sucrose solution in phosphate buffer $(0 \cdot 1 \mathrm{M}, \mathrm{pH} 7 \cdot 3)$ and stored overnight at $4{ }^{\circ} \mathrm{C}$. Samples were frozen and cut using a Slee cryostat (Germany) (10 $\mu \mathrm{m}$ section thickness) and later underwent immunochemical staining.

\section{Luteinizing hormone-releasing hormone (LHRH) test}

A stimulatory test was performed monthly by the i.p. administration of $1 \mu \mathrm{g}$ synthetic LHRH (LUFORAN, Serono, Madrid, Spain) in $0.2 \mathrm{ml}$ saline to all rats. Blood samples were obtained in the morning $(1000 \mathrm{~h})$, under light ether anaesthesia, before (basal value) and $10 \mathrm{~min}$ after the administration of the hypothalamic peptide. Blood was heparinized, immediately centrifuged at $4{ }^{\circ} \mathrm{C}$ and plasma kept frozen at $-20^{\circ} \mathrm{C}$ until analysed for $\mathrm{LH}$ and PRL.

\section{Tissue cultures}

Parotid glands were carefully removed after decapitation of two-day-old female Wistar rats $(n=20)$, and submitted to an initial digestion process with collagenase, hyaluronidase and trypsin (Boehringer-Mannheim, Barcelona, Spain) after mechanical dissection. After several rinses, cells were dispersed with a Pasteur pipette and were allowed to stabilise for one week in RPMI medium supplemented with $10 \%$ fetal calf serum, in 24-well tissue culture plates 
(Corning Inc.). Four different groups of cells were organised, and the different treatments were carried out for 3 weeks, twice a day.

Group 1 ( $n=27$ wells) received, every day, a mixture of synthetic hypothalamic hormones: LHRH (LUFORAN, Serono), growth hormone releasing factor 1-29 $\mathrm{NH}_{2}$ (GEREF, Serono), epidermal growth factor (EGF) (Bachem, Bubendorf, Switzerland), thyrotrophin releasing hormone (TRH) (Prem., Barcelona, Spain) and corticotrophin releasing factor (CRF) (Bachem), at three different concentrations: $2 \mu \mathrm{g}, 4 \mu \mathrm{g}$ and $10 \mu \mathrm{g}$ of each hypothalamic hormone ( $n=9$ wells each) dissolved in $100 \mu \mathrm{l}$ RPMI medium, $50 \mu \mathrm{l}$ in the morning and $50 \mu \mathrm{l}$ in the afternoon. Group $2(n=20$ wells $)$ received twice daily a crude rat acidic hypothalamic extract, prepared according to Lima (1988). The rat hypothalamus was obtained immediately after decapitation, placed in an Eppendorf tube containing $0.5 \mathrm{ml} 0.1 \mathrm{~N}$ $\mathrm{HCl}$ and was boiled for $10 \mathrm{~min}$. Afterwards the tube was transferred to an ice-bath and the tissue homogenized. After adding $0.5 \mathrm{ml} 0.1 \mathrm{~N} \mathrm{HCl}$ with a $0.2 \%$ Triton X-100 solution, the homogenized tissue was centrifuged at 3000 r.p.m. for $30 \mathrm{~min}$ at $4{ }^{\circ} \mathrm{C}$. The supernatant was frozen at $-80^{\circ} \mathrm{C}$ and lyophilized. The lyophilized extract, corresponding to one hypothalamus, was added per day to each well. It was dissolved in $100 \mu \mathrm{l}$ RPMI medium and one half was given in the morning and the other half in the afternoon. A total of 420 hypothalami was used. Group 3 ( $n=20$ wells) received only RPMI medium supplemented with 10\% fetal calf serum and served as culture control, whereas group $4 \quad(n=10$ wells $)$ was used to detect possible contamination of the hypothalamic extract and/or hypothalamic hormones, and consisted of cell-free wells treated with the different experimental mixtures, and submitted to the same incubation procedures as the others. Tissue culture medium $(0.5 \mathrm{ml})$, after adding the treatments, was replaced every 3.5 days from all the wells and substituted with the same amount of fresh medium. Samples were kept frozen at $-20{ }^{\circ} \mathrm{C}$ until analysed.

\section{Hormonal measurements}

Plasma levels, culture medium and fresh pituitary or grafted tissue content of $\mathrm{LH}$ and PRL were measured by double antibody radioimmunoassays (RIA), using reagents provided by the NIDDK and NHPP (School of Medicine, University of Maryland, Baltimore, MD, USA), as previously validated in our laboratory (Tresguerres \& Esquifino 1981). LH was detected at a level of $1 \mathrm{pg} /$ tube LH NIDDK-rat RP-3 (coefficients of variation: intra-assay $<7 \cdot 5 \%$; interassay $<12 \cdot 6 \%$ ) and PRL at a level of $10 \mathrm{pg} /$ tube PRL NIDDKrat RP-3 (coefficients of variation: intra-assay $<5 \%$; interassay $<16 \%)$.
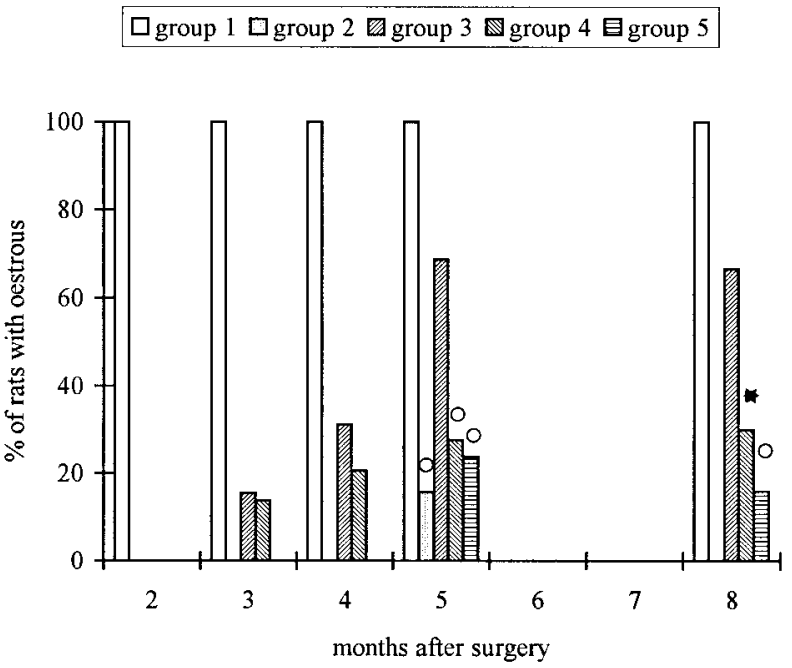

Figure 1 Percentage of female rats showing oestrous cycles after hypophysectomy and grafting in the different groups over a period of 8 months. In group 3 a marked increment can be observed after 3 months ${ }^{\circ} P<0 \cdot 01,{ }^{*} P<0 \cdot 05$ vs group 3 .

Tissue contents of LH and PRL were measured after the homogenization of pituitary or transplanted tissue in saline at $4{ }^{\circ} \mathrm{C}$ using sonication (Branson Sonifier 450). Homogenates were later centrifuged and the supernatant assayed for hormonal content. Protein content was estimated using the Brilliant Blue method (Bradford 1976).

\section{Immunohistochemistry}

Antibodies: antisera to rat prolactin hormone (NIDDKanti-rPRL-IC-4), and to ovine $\beta$ luteinizing hormone (NIDDK-anti-o $\beta$ LH-IC-1) both raised in rabbits, were obtained from Dr A F Parlow (Pituitary Hormones and Antisera Centre, Harbor-UCLA Medical Centre, CA, USA). Frozen pieces of the hypothalamic-pituitary (transplant) areas were removed after intra-aortic perfusion (Andres 1987). Tissue sections, $10 \mu \mathrm{m}$ thick obtained with the Slee cryostat, were washed in PBS $(0 \cdot 1 \mathrm{M}, \mathrm{pH} 7 \cdot 3)$ containing $0 \cdot 2 \%$ bovine serum albumin (PBS-BSA) and then preincubated for 30 min in PBS-BSA containing 30\% normal goat serum. After washing in PBS containing $0 \cdot 1 \%$ Triton X-100 (Sigma, St Louis, MO, USA), sections were incubated in 1:100 dilutions of the first antiserum (see above) diluted in PBS at $4{ }^{\circ} \mathrm{C}$ overnight. After three washes (5 min each) in PBS, sections were incubated for $1 \mathrm{~h}$ in a 1:400 dilution of fluorescein isothiocyanate (FITC)-conjugated goat anti-rabbit immunoglobulin in PBS.

Negative controls were obtained using the same procedure described above, but omitting the primary antibody. 
(a)

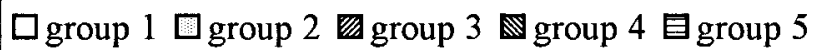

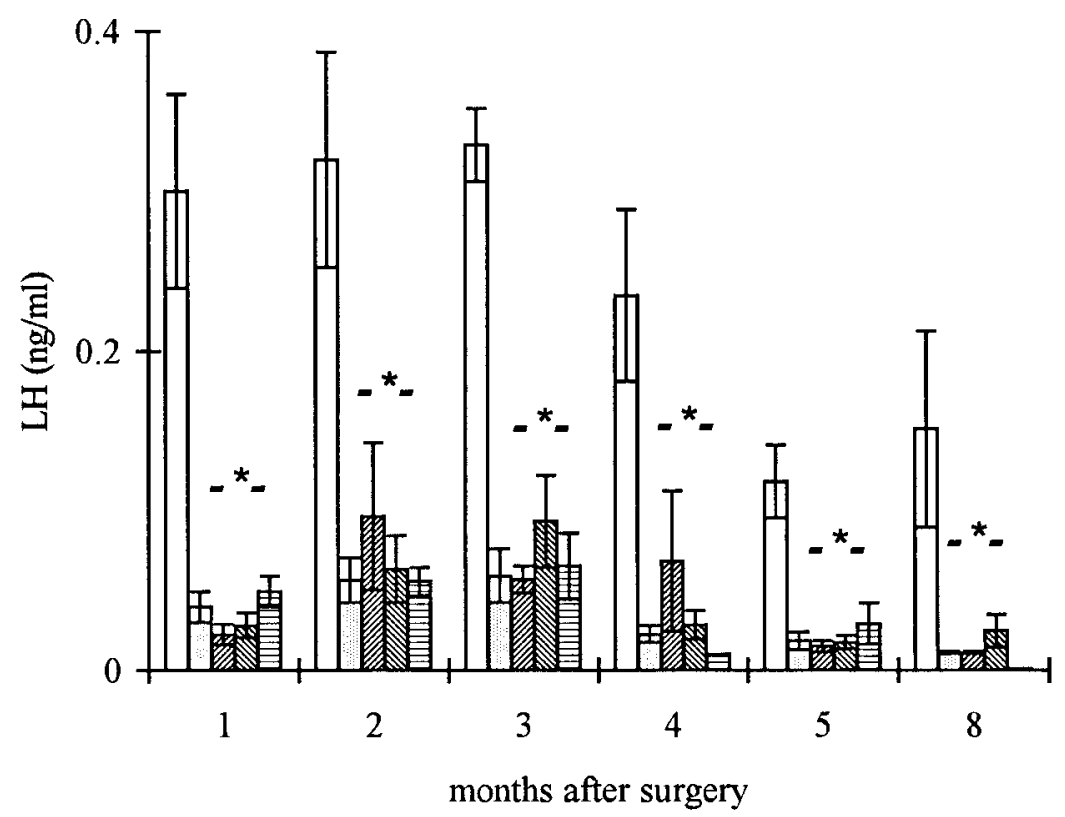

(b)

group 2

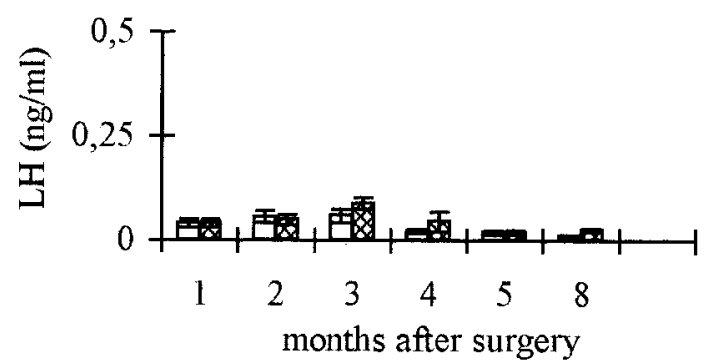

group 3

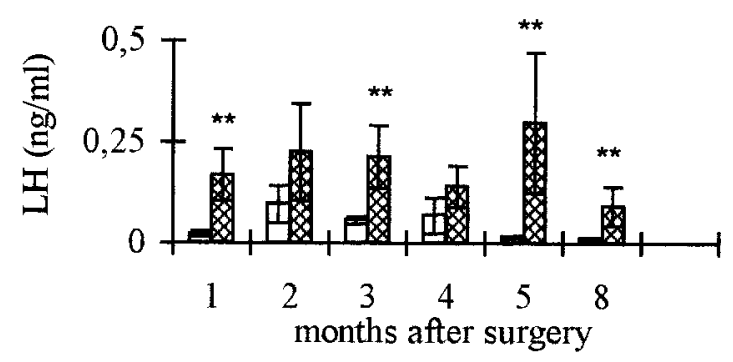

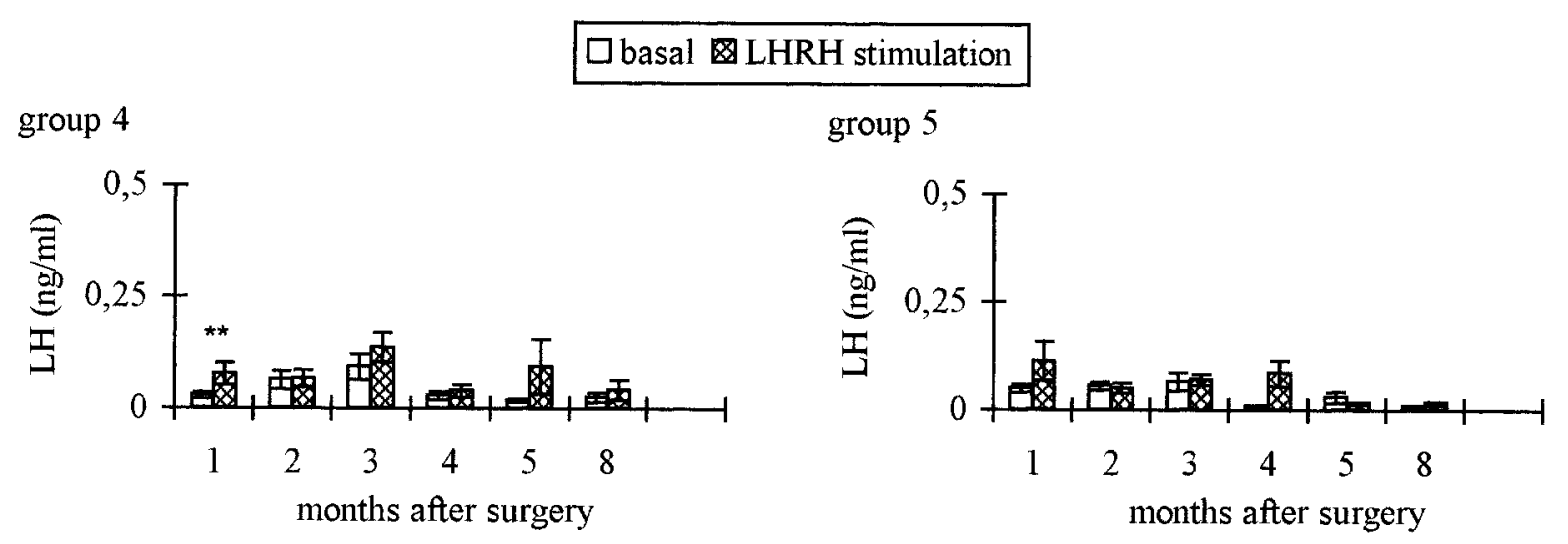

Figure 2 (a) Plasma LH levels in the different groups basally and after LHRH stimulation, over a period of 8 months. All hypophysectomized groups show a marked reduction as compared with controls, ${ }^{*} P<0 \cdot 001$. Parotid gland grafted rats (group 3 ) show a gradual and very clear response as compared with the other groups, as can be seen in more detail in Fig. $2 b,{ }^{*} P<0 \cdot 05$. 
Immunocytochemical procedures for cell culture

Cultured cells were fixed for 5 min with $70 \%$ ethanol. Polyclonal antibodies against LH were used for the study in cell culture as previously described (Fernández 1995). The procedure was as follows: cultured cells were rinsed three times, $5 \mathrm{~min}$ each, in PBS $(0 \cdot 1 \mathrm{M}, \mathrm{pH}$ 7.33). Preincubation was carried out for $30 \mathrm{~min}$ in a PBS solution containing $0 \cdot 1 \%$ Triton $\mathrm{X}-100$. The cells were then incubated overnight at $4{ }^{\circ} \mathrm{C}$, in a solution containing a 1:100 concentration of the primary anti-LH antibody. After three rinses in PBS, 5 min each, cells were incubated for $1 \mathrm{~h}$ in a 1:100 dilution of protein A (Sigma) with phosphate buffer $(0 \cdot 1 \mathrm{M}, \mathrm{pH} 8 \cdot 6)$. Then they were rinsed $(5 \mathrm{~min}$ each) twice in PBS, and once in Tris buffer (0.05 M, pH 7.6). The immunocytochemical reaction was developed with 0.5\% 3,3,p-diaminobenzidine (Sigma) and $0 \cdot 34 \%$ hydrogen peroxidase (Sigma). Cells were rinsed three times $(5 \mathrm{~min}$ each) in Tris buffer $(0 \cdot 05 \mathrm{M}, \mathrm{pH} 7 \cdot 6)$. Negative controls were obtained using the same procedure described above, but omitting the primary antibody.

\section{Data analysis and presentation}

Immunolabelled cells were visualized with light microscopy using a Nikon Laborlux photomicroscope for tissue sections, or a Leica inverted photomicroscope for cultured cells. Cells were counterstained by the Gomori technique.

Quantitative results were analysed by one-way analysis of variance, followed by the method of least significant difference. Data for all experiments are presented as means \pm S.E.M.

\section{Results}

\section{Vaginal smears}

Vaginal smears obtained daily after the operation showed that animals in groups 2, 3, 4, and 5 were in a permanent dioestrous state, whereas among unoperated control animals $16 \%$ were in pro-oestrus and $36 \%$ were in oestrus (Fig. 1). Three months following operation, some oestrous smears were observed in groups 3 and 4 , whereas animals in groups 2 and 5 remained in constant dioestrus. Three, four, five and eight months after the operation, the number of animals from groups 3 and 4 showing oestrous cycles increased gradually, reaching $69 \%$ in group 3 and $40 \%$ in group 4 at five months and maintaining these figures at eight months. Unoperated control animals showed regular cycles during the entire experiment (Fig. 1).

\section{Plasma hormone levels}

Plasma LH levels were significantly lower $(P<0 \cdot 001)$ in all hypophysectomized groups compared with controls at all $\square$ group $1 \square$ group 2 group 3 group 4 南 group 5

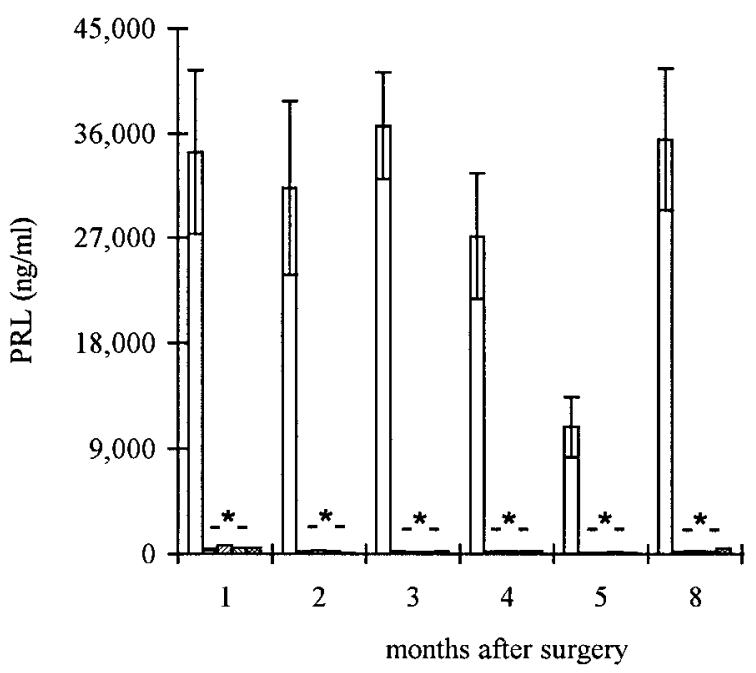

Figure 3 Plasma prolactin levels over 8 months in the different groups after hypophysectomy and various transplants in the hypothalamic-pituitary area. All transplanted groups show a significant decrease vs controls, ${ }^{*} P<0 \cdot 001$.

times studied (Fig. 2a). However, beginning at 1 month a gradual increase in the LH response to LHRH was detected in the parotid gland transplanted group. These animals showed a significant $(P<0 \cdot 05)$ increase in $\mathrm{LH}$ plasma levels after LHRH stimulation in months 1, 3, 5 and 8 . The adrenal gland transplanted group also showed a small increase in LH response to LHRH that was significant $(P<0 \cdot 05)$ in the first month. No effect at all was observed in muscle transplanted rats or those with cement (Fig. 2b).

Plasma PRL concentrations in all the hypophysectomized animals (group $2=237 \pm 96 \mathrm{pg} / \mathrm{ml}$, group $3=369 \pm 104 \mathrm{pg} / \mathrm{ml}$, group $4=265 \pm 49 \mathrm{pg} / \mathrm{ml}$ and group $5=99 \pm 7 \cdot 7 \mathrm{pg} / \mathrm{ml})$ were significantly lower $(P<0 \cdot 001)$ than those in the control group $(2404 \pm 757 \mathrm{pg} / \mathrm{ml})$. No statistical differences were found among groups $2,3,4$ and 5 (Fig. 3).

\section{LH and PRL graft content}

The graft was macroscopically recognisable after careful dissection of the hypothalamic-pituitary area, both in perfused rats (Fig. 4(a)) and in fresh tissue. At low magnification, the graft showed a central and wide necrotic area (Fig.4(b)). Graft LH content in group 3 animals showed values significantly lower $(P<0.001)$ than those of normal pituitary glands (graft $=0 \cdot 036 \pm 0 \cdot 011 \mu \mathrm{g} /$ mg protein vs normal pituitary $=1 \cdot 8 \pm 0.3 \mu \mathrm{g} / \mathrm{mg}$ protein), but significantly higher than normal parotid gland tissue in which LH content was below the detection limit. Also, the 

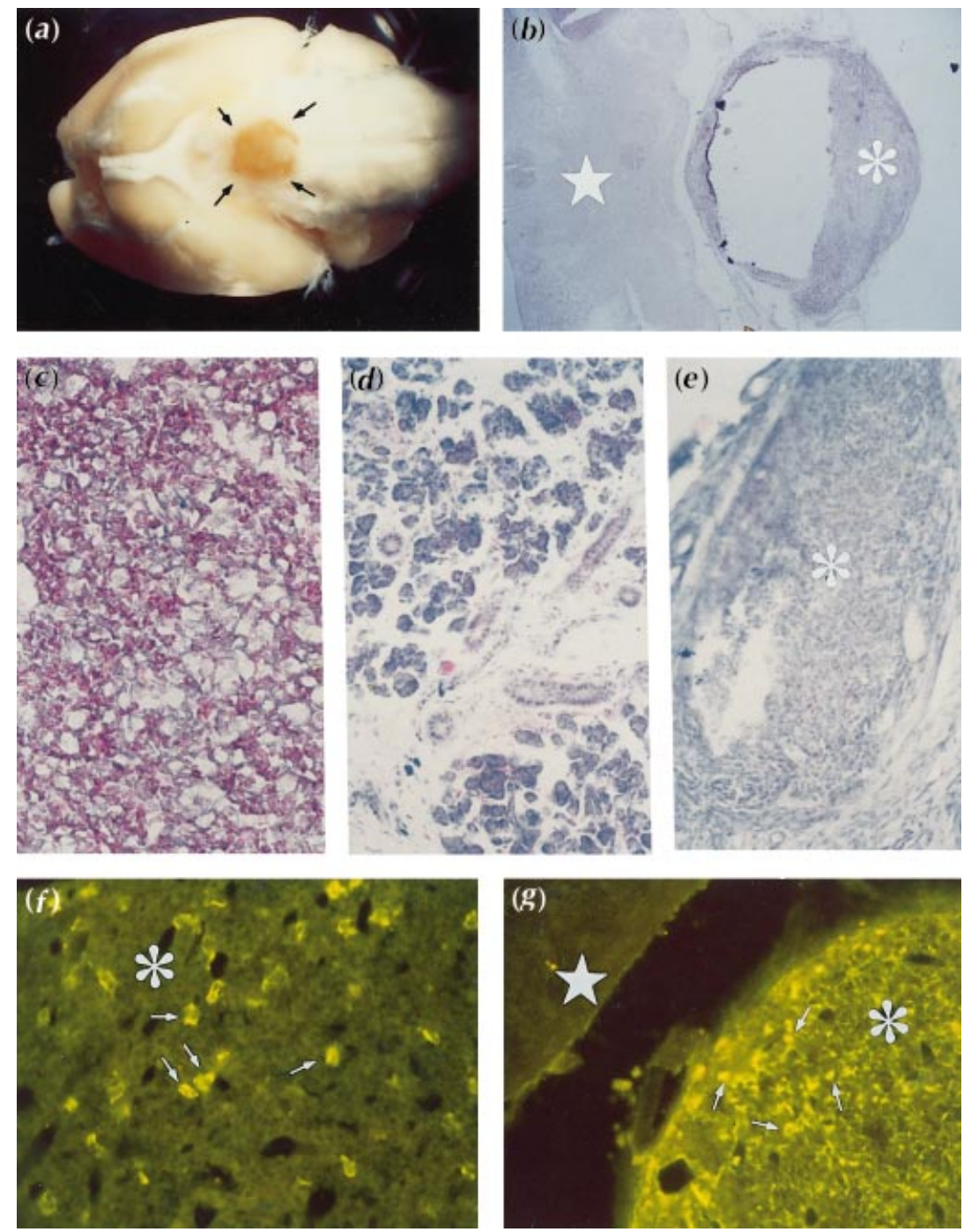

Figure 4 (a) Parotid gland transplant located in the hypothalamic area. (b) Low magnification general view of the transplant, in contact with the hypothalamic tissue, with a central necrotic area. (c) Gomori-stained pituitary tissue (magnification $\times 300$ ). $(d)$ Gomori-stained parotid gland tissue in situ (magnification $\times 300)$. (e) Gomori-stained transplanted parotid gland in the sella turcica (magnification $\times 300$ ). $(f)$ Immunostaining of transplanted parotid gland with anti-LH antibody (marked by arrows)

(magnification $\times 800)$. $(\mathrm{g})$ Immunostaining of transplanted parotid gland with anti-PRL antibody (marked by arrows) (magnification $\times 250$ ). Star, hypothalamic tissue; asterisk, transplanted parotid gland tissue.

LH content of the parotid transplant in group 3 rats was higher than in the grafts of group $4(0 \cdot 0193 \pm 0 \cdot 008 \mu \mathrm{g} /$ $\mathrm{mg})$ and significantly higher $(P<0 \cdot 05)$ than in group 5 $(0 \cdot 0108 \pm 0 \cdot 0037 \mu \mathrm{g} / \mathrm{mg})$ animals (Fig. 5). The PRL content of normal parotid gland tissue was $0.0011 \pm$ $0 \cdot 0001 \mu \mathrm{g} / \mathrm{mg}$, whereas the transplant in group 3 animals showed a significant increase amounting to $0 \cdot 0034 \pm$ $0.0008 \mu \mathrm{g} / \mathrm{mg}$ protein, although significantly lower than those of pituitary glands $(4 \cdot 7 \pm 0.8 \mu \mathrm{g} / \mathrm{mg}$ protein). There were no significant differences among PRL contents in any of the transplants (group 4=0.0031 $\pm 0.0006 \mu \mathrm{g} / \mathrm{mg}$ and group $5=0 \cdot 0053 \pm 0 \cdot 0015 \mu \mathrm{g} / \mathrm{mg}$ ).

\section{Immunohistochemistry}

Pituitary glands of control animals, stained with the Gomori technique, showed the three typical adenohypophyseal cell types: acidophilic, basophilic and chromophobic. Acidophilic cells appeared more frequently 


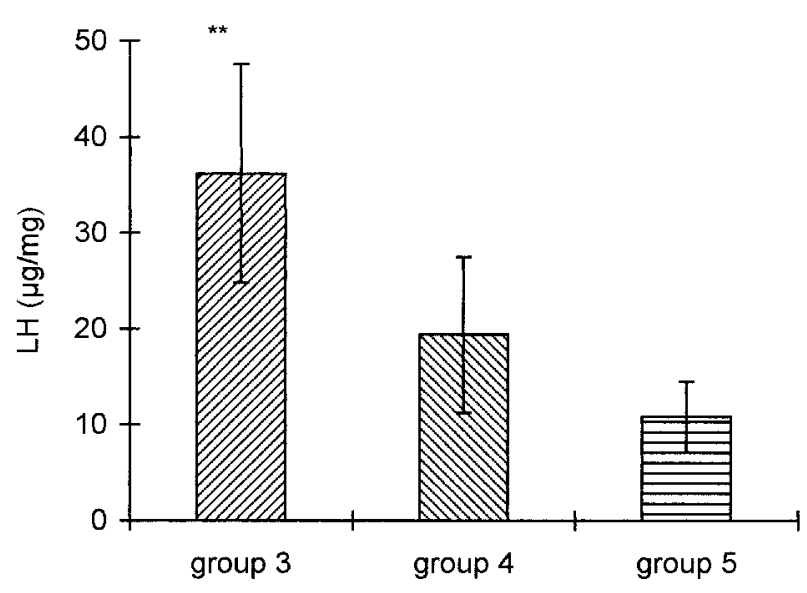

Figure $5 \mathrm{LH}$ content in the different grafts. Only the parotid gland transplant (group 3) shows significant LH content compared with the other groups, ${ }^{* *} P<0 \cdot 05$.

than the other two types, and were homogeneously distributed along the adenohypophysis (Fig. $4(c)$ ) as has already been described. Sections of in situ parotid gland stained with the Gomori technique showed acinar glands inside connective tissue (Fig. 4(d)). No cells of the type observed in the adenohypophysis (Fig. 4(c)) were present in the parotid gland. However, the grafted parotid tissue in the sella turcica (Fig. 4(e)) showed a number of growing nodules of cells larger than those appearing in the parotid gland but smaller than those in the adenohypophysis. Some degree of structural transformation was observed in the histological examination using Gomori staining, with a certain degree of acidophilia.

Immunostaining with anti-LH antibodies (Fig. 4(f)) and anti-PRL antibodies (Fig. $4(g)$ ) showed the presence of positive cells in the grafted parotid tissue. LH reactive cells were an oval shape and appeared sparsely distributed within the grafted tissue (Fig. $4(f)$ ). A surprising number of PRL immunoreactive cells appeared in the grafted parotid (Fig. $4(g)$ ). These cells were round in shape and different from the other cell types.

\section{Tissue cultures}

Parotid epithelial cells placed in tissue culture were usually observed forming clusters of round-plated cells. However, some round cells appeared isolated in the culture. In both configurations, a clear association was observed between epithelial cells and fibroblasts derived from the parotid gland stroma.

LH concentration in the culture medium of the wells treated with $10 \mu \mathrm{g}$ of the mixture of synthetic hypothalamic hormones (HF) is shown in Fig. 6. A significant increase in $\mathrm{LH}$ can be seen at $1(80 \pm 13 \mathrm{pg} / \mathrm{ml})$ and 1.5 $(128 \pm 14 \mathrm{pg} / \mathrm{ml})$ weeks of culture, even with the lowest

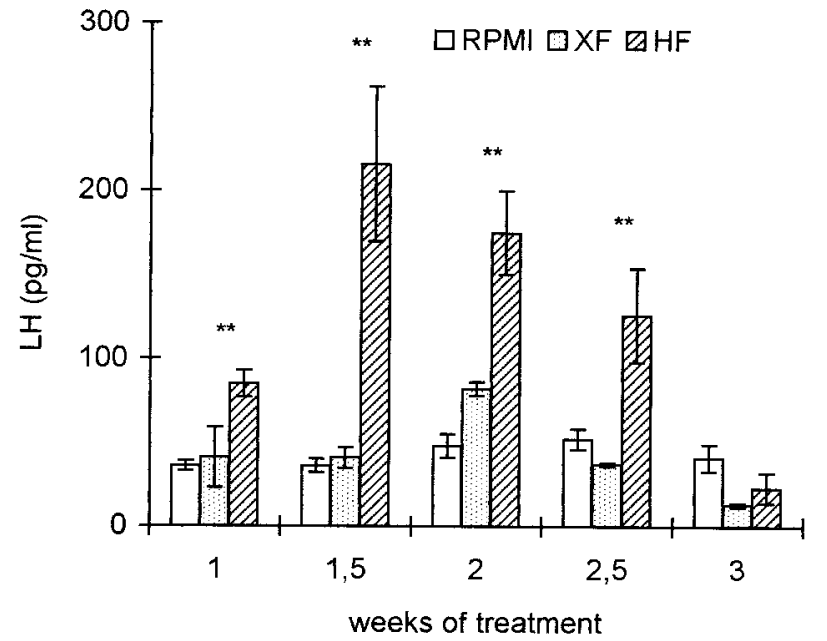

Figure 6 LH concentration in the culture medium of parotid gland cells treated with medium only (RPMI) or with a mixture of $10 \mu \mathrm{g}$ of each synthetic hypothalamic hormone (HF). A further group of wells without cells was treated with the mixture to eliminate the possibility of contamination with pituitary hormones (XF). ${ }^{* *} P<0 \cdot 05$, values significantly higher in HF compared with XF or RPMI.

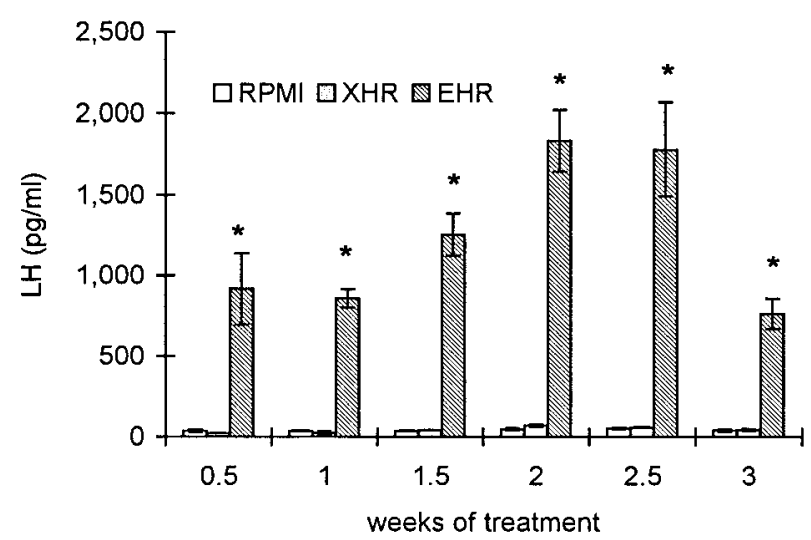

Figure $7 \mathrm{LH}$ concentration in the culture medium of parotid gland cells treated with medium (RPMI) or a crude rat hypothalamic extract (EHR). XHR were wells without cells to avoid the possibility of contamination of the hypothalamic extract with pituitary hormones. ${ }^{\star} P<0 \cdot 001$, values significantly higher in EHR compared with RPMI or XHR.

dose ( $2 \mu \mathrm{g}$ of each hormone), and a certain dose-related response can be observed $(132 \pm 8 \mathrm{pg} / \mathrm{ml}$ with $4 \mu \mathrm{g}$ hypothalamic hormone mixture and $216 \pm 46 \mathrm{pg} / \mathrm{ml}$ with $10 \mu \mathrm{g}$ hypothalamic hormone mixture) at 1.5 weeks. $\mathrm{LH}$ concentration in the medium only treated parotid cells (RPMI) was $41 \pm 6 \mathrm{pg} / \mathrm{ml}$ and in the wells with the hormone mixture without cells (XF) LH concentration was $36 \pm 4 \mathrm{pg} / \mathrm{ml}$.

When a crude rat hypothalamic extract (EHR) instead of the synthetic hormone mixture was used, the appearance of the pituitary hormones was quicker and more marked. In Fig. 7, it can be seen that $\mathrm{LH}$ values 

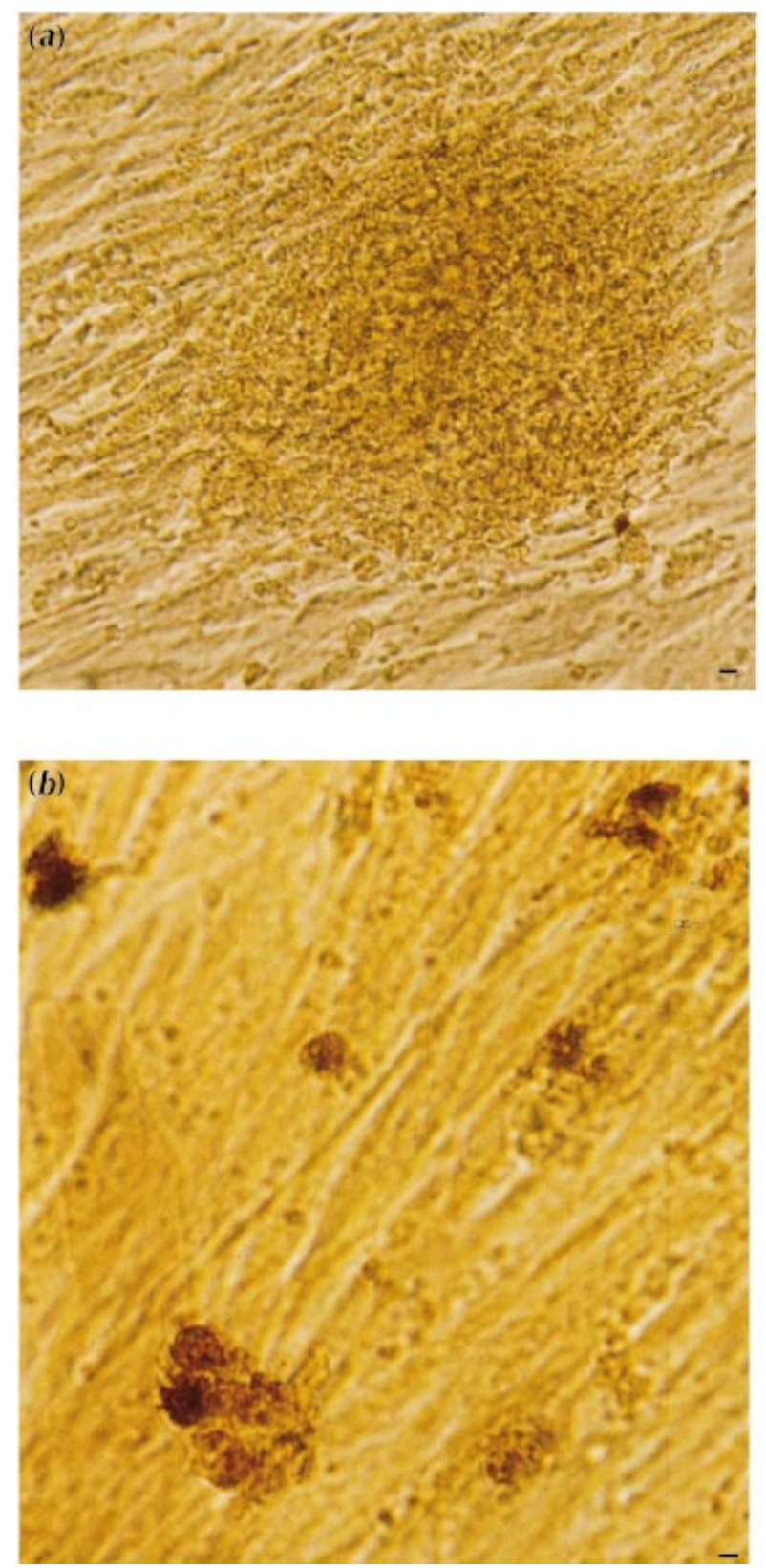

Figure 8 (a) Negative immunostaining with an anti-LH antibody $(1: 70)$ of parotid cells in culture with control medium (RPMI) (magnification $\times 250)($ Scale bar represents $100 \mu \mathrm{m}$.). (b) Positive immunostaining of parotid cells in culture treated with crude hypothalamic rat extract at a dose of 1 hypothalamus/day/well (magnification $\times 400$ ) (Scale bar represents $50 \mu \mathrm{m}$.).

are significantly higher from 3.5 days onwards in EHR-treated cultures than in control cultures treated with RPMI only, or wells without tissue treated with the extract (XHR) $(\mathrm{EHR}=917 \pm 222 \mathrm{pg} / \mathrm{ml}$ to $1834 \pm$ $190 \mathrm{pg} / \mathrm{ml} ; \quad$ control $=36 \pm 3 \mathrm{pg} / \mathrm{ml}$ to $52 \pm 6 \mathrm{pg} / \mathrm{ml}$; $\mathrm{XHR}=23 \pm 3 \mathrm{pg} / \mathrm{ml}$ to $69 \pm 6 \mathrm{pg} / \mathrm{ml})$. The same pattern emerges for PRL values. Immunostaining of the cultured cells demonstrates that only epithelial round cells are immunoreactive for $\mathrm{LH}$.

Immunoreaction for each antibody, which appeared as a dark staining of peroxidase, was observed in some cells of each cluster; other cells remained non-immunoreactive. This suggests that some cells could specifically synthesize a particular hormone, while other cells remain undifferentiated for hormone synthesis (Fig. 8).

\section{Discussion}

Since the work of Patterson and Chun (1977), we know that environmental factors are crucial for cellular differentiation. In the case of neurons from the autonomous nervous system, different morphologies and neurotransmitters were produced according to the hormonal microenvironment, determined by the different parts of the organism where they were developed. Furshpan et al. (1986) showed that sympathetic neonatal neurons cultured together with cardiac myocytes, were able to change from adrenergic to cholinergic neurons. This was also confirmed by Potter et al. (1986), by the observation that the composition of the culture medium exerted an important role in the differentiating process. These authors also demonstrated that the morphofunctional changes were possible not only in immature cells, but also in neurons obtained from adult animals, although the modifications were not as easily induced as in the former. Greene and Tischler (1987) observed that highly differentiated PC12 cells derived from a phaeochromocytoma were also able to change their morphofunctional characteristics in the presence of nerve growth factor, displaying a very similar phenotype to that of sympathetic neurons.

Morphofunctional changes have also been induced by hormones in cells obtained from adult animals. Bellows et al. (1990) observed that in osseous cells, parathyroid hormone (PTH) was able to suppress the passage of osteoprogenitor cells to functional osteoblasts, and Kasperk et al. (1990) found that androgens stimulated differentiation and mitogenesis. Yeh et al. (1989) showed that corticosterone was able to induce differentiation of intestinal cells in adrenalectomized lactating rats and $\mathrm{Xu}$ and Bjorntorp (1987) demonstrated that sexual hormones played an important role in the differentiation of precursors of adipose cells. Morphofunctional changes have also been shown in endocrine cells. Inoue \& Sakai (1991) showed that $\mathrm{MtT} / \mathrm{S}$, a pituitary cell line that secreted growth hormone $(\mathrm{GH})$, was able to secrete PRL with insulin-like growth factor-I (IGF-I) or insulin stimulation.

Hoeffler \& Frawley (1987) have shown that hypothalamic factors are capable of modifying the proportion of GH or PRL secreting cells in the pituitary tissue in vitro, thus indicating their ability to induce differentiation. Factors that do not normally influence acute release of 
PRL or GH can exert a chronic effect on the proportion of cells that secrete these hormones. Other authors have produced similar data in rat embryonic pituitaries with both TRH (Heritier \& Dubois 1993) and LHRH (Heritier \& Dubois 1994) administration.

In our data, the appearance of oestrous cycles in some rats after 3-4 months of parotid grafting, confirmed previous data from Alvarez-Buylla et al. (1973) in dogs. These data were obtained simultaneously with a significant increase in the plasma $\mathrm{LH}$ response to LHRH stimulation and confirmed the transdifferentiation of the salivary cells in pituitary tissue as shown by the initial data of our group (Alvarez-Vega et al. 1991). The production of LH could also be observed, although less markedly, in adrenal transplanted rats, but not in muscle transplanted rats or in hypox rats with cement in the sella turcica. Graft LH content was also higher in parotid gland transplanted animals than in the other hypox groups.

The parotid gland transplanted group showed the highest percentage of animals in oestrus, a significant response of plasma LH to LHRH stimulation, and the highest LH content in the transplant. This seemed to be due to a more marked transdifferentiating capability of the parotid gland under stimulation of the hypothalamic hormones compared with other tissues. The high local EGF content known to stimulate gonadotrophins (Armstrong \& Childs 1997) as well as other growth factors could play an important role. However, it is also possible that undifferentiated cells reside within the parotid gland and that these cells, under hypothalamic influence and with the help of the local growth factors, differentiate to produce pituitary hormones. Our data do not rule out this possibility.

\section{Immunohistochemistry techniques}

Our results indicate that LH and PRL immunostained cells are present in the grafted parotid tissue. No positive immunostaining was observed in the normal parotid gland, in contrast to the normal pituitary where the hormones (LH, PRL) were present in many cells. In all cases, the grafted tissue retained part of its original structure (Fig. 4(e)), suggesting that LH and PRL cells are not part of remnant pituitary gland but have been formed by transdifferentiation of the parotid cells, as was postulated previously by Alvarez-Buylla and Alvarez-Buylla (1963).

Horacek et al. (1989) demonstrated that LHRH treatment was able to induce differentiation of gonadotrophic and lactotrophic cells in embryonic pituitary tissue transplanted under the renal capsule in adult hypophysectomized and orchidectomized hamsters. After losing its portal connections, the adult pituitary gland transplanted under the kidney capsule also undergoes morphofunctional changes (Tresguerres \& Esquifino 1983), showing an increase in PRL secretion. Other studies by Nemeskéry et al. (1976) have shown that in order to undergo full differentiation, the differentiating pituitary needed to be located in the sella turcica where the pituitary cells are under the influence of hypothalamic hormones. In Fig. $4(b)$, the contact surface between the hypothalamus and the graft can be clearly observed, making possible the transfer of hypothalamic factors.

In the study by Alvarez-Buylla et al. (1973) dogs bearing grafts of parotid glands in place of the pituitary since their infancy were able to mate when adults, give birth to pups and recover some adrenal and thyroidal function, but did not reach a normal size and were also unable to lactate. This suggests that neither GH nor PRL were produced by the graft. This was apparently because of the special hypothalamic dual control of both hormones, with stimulatory and inhibitory peptides and a great predominance of the latter (Tresguerres \& Esquifino 1981, 1983, Devesa et al. 1992). Interestingly, in this study immunostaining with PRL antibodies showed positive cells in the graft, although these were not as evident as with $\mathrm{LH}$ antibodies. This could be explained by the presence of PRL in the lymphoblastic cells (DiMattia et al. 1988). Another possibility is the existence of a very limited PRL synthesis without secretion (due to its predominantly inhibitory hypothalamic control; Tresguerres \& Esquifino 1981, 1983) and that this is insufficient to support lactation.

In vitro culture experiments were carried out to prove that the presence of pituitary hormones in the parotid gland transplanted animals was, in fact, coming from the transdifferentiated parotid cells, and not from potential pituitary remnants, and that the hypothalamic hormones stimulated this process. The in vitro culture experiments were performed in a similar way as those previously shown for acinar parotid cells by Fritz et al. (1980) and Oliver (1980). In our experiments, both isolated epithelial cells and cell aggregates were observed in the culture, as previously described by Sabatini et al. (1991) and Prasad et al. (1992), growing on a fibroblast layer. Fibroblasts, as in other primary tissue cultures, originated from the primary tissue explant and were very important for the survival of the epithelial cells. The use of a medium with D-valine (MEM D-Val; Gibco, Paisley, UK), resulted in the disappearance of fibroblasts, epithelial cell loss of anchoring and cell death. Fibroblasts did not seem to interfere with hormonal production in any other way. The cellular viability was $82 \%$ and the confluence time was four days for the fibroblasts. From this day on, epithelial glandular cells also started to aggregate.

LH and PRL were detected in the culture medium obtained from wells treated with synthetic hypothalamic hormones under these conditions for 1 and 1.5 weeks. The pituitary hormone concentrations were small but significantly higher than in control or in cell-free wells, which should be regarded more as non-specific RIA interference. However, in the wells treated with the crude rat hypothalamic extract, LH levels dramatically increased as early as 3.5 days of culture reaching more than 20 times the 
values found in control or in cell-free wells by week 2 , thus indicating a clear capacity of the parotid cells to produce pituitary hormones. Our results suggest that in addition to the hypothalamic hormones, other factors only present in the extract have the capacity to induce fully the production of pituitary hormones by the parotid gland.

The influence of the dopaminergic system with a predominantly inhibitory action on PRL, could explain the absence of PRL in vivo, whereas in the in vitro studies this influence may be overcome by the presence of stimulatory factors (Tresguerres \& Esquifino 1981).

There are no experimental data clearly demonstrating whether all of the pituitary glandular cell types derive from the same progenitor cells. Frawley \& Boockfor (1991) supported the existence of a common lineage for lactotrophs and somatotrophs in rats. On the other hand, gonadotrophs and thyrotrophs both secrete the same $\alpha$ subunit shared by thyrotrophin (TSH) and gonadotrophins (Pierce \& Parsons 1981). Heritier \& Dubois (1993) demonstrated that TRH was able to induce gonadotroph and LHRH could induce thyrotroph (Heritier \& Dubois 1994) differentiation when introduced early in the culture of embryonic pituitary cells. With the use of cultures of fetal rat pituitary primordia, researchers were able to establish the factors controlling the development of the pituitary cells (Nemeskéry et al. 1976, Begeot et al. 1983). LHRH and TRH were found to be necessary for the differentiation. Also, it was demonstrated that a single hypothalamic hormone was able to induce the differentiation of more than one pituitary cell type (Heritier \& Dubois 1994). Conversely, one pituitary cell phenotype could be induced by more than one factor (Begeot et al. 1984, Heritier \& Dubois 1994).

The presence of $\alpha$ and $\beta$ subunits of human chorionic gonadotrophin/LH has been described in numerous tumoral cell types (Beck-Peccoz et al. 1993, Acevedo et al. 1995, Bidart et al. 1997) displaying autocrine or paracrine functions (Bidart et al. 1997) mainly in tumour growth.

Transcriptional factors are involved in the initiation of the expression of several hormonal genes (Gordon et al. 1993), including those of GH, PRL and TSH (Simmons et al. 1990), and also in the transformation of pituitary adenomas, and therefore mediate the effect of hypothalamic factors (Sanno et al. 1996).

Since only parotid cells were seeded for our primary culture, the appearance of pituitary hormones could only be due to the induction of pituitary phenotype in some of these cells or to the activation of uncommitted precursors within the salivary gland. Our results are consistent with all the evidence presented above, indicating that the hypothalamus plays an important role in the induction of pituitary differentiation (Denef 1986) and shows that cells in other tissues had the capacity to respond to the signals.

Probably, the parotid gland, due to its particular characteristics, is especially suitable for a morphofunctional change. Pituitary hormones have been found to be pro- duced during ontogeny (Shirasawa et al. 1996) in lung and stomach cells of chick embryos, thus confirming that at least over a certain period, pituitary hormones can be produced in normal extra-pituitary tissues. GH has also been demonstrated in human thymomas by immunohistochemistry and in situ hybridization (Lauriola et al. 1997).

LHRH has been shown to be necessary for the differentiation of lactotrophic cells (Begeot et al. 1983, Tilemans et al. 1991). Since GHRH-induced pit-1 has also been shown to be necessary for PRL gene activation ( $\mathrm{Li}$ et al. 1990), the probable interactions of both hypothalamic hormones is mandatory for the development of lactotrophic cells (Kendall et al. 1991). TRH was capable of stimulating not only thyrotrophs, but also the differentiation of gonadotrophs (Heritier \& Dubois 1993). Whether the expression of each phenotype requires the synergistic action of more than one factor or each of them is capable of stimulating various cell types, remains to be determined. The higher response obtained with the crude rat hypothalamic extract as compared with the synthetic hormones, was probably due to the presence of an unknown growth factor(s) in the former, which could be responsible for both the transdifferentiating ability and cell survival, as demonstrated for tri-iodothyronine and cortisol in the differentiation process of somatotrophs (Hemming et al. 1988).

The long delay in the grafts assuming the new functions in vivo seems to be related to the adult characteristics of the parotid cells, and to the delay in getting the hypothalamic blood supply which, in any case, may have been insufficient for a rapid and complete vascularization. In the initial period after the grafting, the tissue probably underwent a certain amount of degeneration (Spira et al. 1988). After the appearance of the blood vessels and the portal blood carrying the hypothalamic factors, a new differentiating process takes place (Alvarez-Buylla \& Tsutsumi 1979). Thus, the tissue obtains characteristics of pituitary cells, as shown both by the plasma levels of $\mathrm{LH}$, and by the immunohistochemical staining. In contrast, this process was very rapid in vitro. The appearance of $\mathrm{LH}$ after only 3.5 days of culture in the presence of hypothalamic extracts, indicated that in the stabilised cultured cells, the process can take place at a much higher speed than in vivo. In vitro, the hypothalamic hormones were very concentrated and had easy access to the cells.

In conclusion, parotid cells submitted to hypothalamic hormones are capable of changing their function and morphology (transdifferentiation) to pituitary hormone producing cells both in vivo and in vitro.

\section{Acknowledgements}

This work has been made possible through FIS grants 92/475 and 96/1084.

We are indebted to the NIADDK for the generous supply of the reagents for pituitary hormone determi- 
nation. The invaluable help of L Kraus and E AlvarezBuylla is gratefully acknowledged. We also thank A Alvarez-Buylla from the Rockefeller University (New York) for the careful revision of the manuscript.

\section{References}

Acevedo HF, Tong JY \& Hartsock RJ 1995 Human chorionic gonadotropin $\beta$-subunit gene expression in cultured human fetal and cancer cells of different types and origins. Cancer $\mathbf{7 6}$ 1467-1475.

Alvarez-Buylla R 1970 Método de substitución de la hipófisis por un fragmento de parótida en la rata. XII Congreso Nacional de Ciencias Fisiológicas. Morelia, México.

Alvarez-Buylla R \& Alvarez-Buylla ER 1963 Regulation of hypoglycemia in hypophysectomized dogs with glandular transplants in the sella turcica. Acta Physiológica Latino Americana 13 306-312.

Alvarez-Buylla R \& Alvarez-Buylla ER 1964 Eosinopenia provoked by insulin in dogs in which the hypophysis has been substituted by transplants of salivary gland or adrenal tissue. Acta Physiológica Latino Americana 14 245-250.

Alvarez-Buylla R \& Alvarez-Buylla ER 1970 Adrenocortical activity in normal dogs, hypophysectomized dogs and dogs with a transplant of salivary gland in the place of the extirpated hypophysis. Acta Physiológica Latino Americana 20 93-96.

Alvarez-Buylla R \& Tsutsumi V 1979 Adrenocortical function in hypophysectomized dogs with parotid gland transplants in direct contact with the basal hypothalamus. Acta Endocrinologica 92 710-719.

Alvarez-Buylla R, Mandoki J \& Alvarez-Buylla ER 1970a Survival comparison between totally hypophysectomized dogs and dogs with a transplant of salivary gland in the place of the extirpated hypophysis. Acta Physiológica Latino Americana 20 20-23.

Alvarez-Buylla R, Erlij D \& Alvarez-Buylla ER $1970 b^{131}$ I uptake by thyroid of hypophysectomized dogs with salivary gland transplants in the sella turcica. Acta Physiologica Latino Americana 20 13-19.

Alvarez-Buylla R, Deleón I \& Alvarez-Buylla ER 1973 Gonadal function in hypophysectomized dogs with glandular transplants in the sella turcica. Acta Physiológica Latino Americana 23 75-82.

Alvarez-Vega P, Gil-Loyzaga P, Alvarez-Buylla R \& Tresguerres JAF 1991 Partial pituitary function of parotid gland tissue autotransplanted to the sella turcica after hypophysectomy. 73rd Annual Meeting of the Endocrine Society, Washington (Abstract) 1542.

Andres KH 1987 Zur methodik der perfusions fixierung des zentral nervensystem von Säugern. Mikroskopie 21 169-174.

Armstrong J \& Childs GV 1997 Changes in expression of epidermal growth factor receptors by anterior pituitary cells during the estrous cycle: expression by gonadotropes. Endocrinology 138 1903-1908.

Beck-Peccoz P, Todaro F, Persani L \& Cortelazzi D 1993 Pituitary gonadotropin-secreting tumors. In Hormones in Gynecological Endocrinology, pp 185-196. Eds AR Gennazzani \& F Petraglia. Carnfoth: Parthenon Publishing.

Begeot M, Hemming FJ, Martinat N, Dubois MP \& Dubois PM 1983 Gonadotropin releasing hormone $(\mathrm{GnRH})$ stimulates immunoreactive lactotrope differentiation. Endocrinology 112 2224-2226.

Begeot M, Morel G, Rivest RW, Aubert ML, Dubois MP \& Dubois PM 1984 Influence of gonadoliberin on the differentiation of rat gonadotrophs: an in vivo and in vitro study. Neuroendocrinology 38 $217-225$.

Bellows CG, Ishida H, Aubin JE \& Heersche JNM 1990 Parathyroid hormone reversibly suppresses the differentiation of osteoprogenitor cells into functional osteoblasts. Endocrinology 127 3111-3116.

Bidart JM, Bardin E, Troalen F, Bellet D \& Schlumberger M 1997 Production eutopique et ectopique des sousunités $\alpha$ et $\beta$ des hormones glycoproteiques. Annales d'Endocrinologie 58 125-128.

Bradford MM 1976 A rapid and sensitive method for the quantification of microgram quantities of protein utilising the principle of protein-dye binding. Annals of Biochemistry 72 248-254.

Denef C 1986 Paracrine interactions in the anterior pituitary. Clinical Endocrinology 15 1-31.

Devesa J, Lima L \& Tresguerres JAF 1992 Neuroendocrine control of growth hormone secretion in humans. Trends in Endocrinology and Metabolism 3 175-182.

DiMattia GE, Gellersen B, Bohnet HG \& Friesen HG 1988 A human B-lymphoblastoid cell line produces prolactin. Endocrinology 122 2508-2517.

Fernández P 1995 Transformación de las células glandulares parotideas sometidas a influencias hormonales hipotalámicas. Estudio in vitro. PhD thesis, Facultad de Ciencias Biológicas, Complutense University. Madrid, Spain.

Frawley LS \& Boockfor FR 1991 Mammosomatotrophs: presence and functions in normal and neoplastic pituitary tissue. Endocrine Reviews 12 337-355.

Fritz ME, LaVeau P \& Nagmias AJ 1980 Primary cultures of feline acinar cells: dissociation, culturing and viral infection. American Journal of Physiology 239 G288-G294.

Furshpan EJ, Landis SC, Matsumoto SG \& Potter DD 1986 Synaptic functions in rat sympathetic neurons in microcultures. I. Secretion of norepinephrine and acetylcholine. Journal of Neuroscience $\mathbf{6}$ 1061-1079.

Gordon DF, Haugen BR, Sarapura VD, Nelson AR, Wood WM \& Ridgway EC 1993 Analysis of Pit-l in regulating mouse TSH $\beta$ promoter activity in thyrotropes. Molecular Cell Endocrinology 96 $75-84$.

Greene LA \& Tischler AS 1987 Pheochromocytoma cells (PC 12) tumor cell line. In Encyclopedia of Neuroscience, pp 938-939. Ed G Edelmal. Boston, USA: Birkhläser.

Hemming FJ, Aubert ML \& Dubois PM 1988 Differentiation of fetal rat somatotropes in vitro: effects of cortisol, 3,5,3'-triiodothyronine, and glucagon - a light microscopic and radioimmunological study. Endocrinology 123 1230-1236.

Heritier AG \& Dubois PM 1993 Influence of thyroliberin on the rat pituitary cell type differentiation: an in vitro study. Endocrinology 132 634-639

Heritier AG \& Dubois PM 1994 Re-evaluation of gonadotropinreleasing hormone $(\mathrm{GnRH})$ action on pituitary cell differentiation with special regard to its effect on LH and TSH cell types. Journal of Neuroendocrinology 6 33-37.

Hoeffler JP \& Frawley LS 1987 Hypothalamic factors differentially affect the proportions of cells that secrete growth hormone or prolactin. Endocrinology 120 791-795.

Horacek MJ, Campbell GT \& Blake CA 1989 Luteinizing hormone (LH)-releasing hormone: effects on induction of LH, folliclestimulating hormone, and prolactin cell differentiation. Endocrinology 124 1800-1806.

Inoue K \& Sakai T 1991 Conversion of growth hormone-secreting cells into prolactin-secreting cells and its promotion by insulin-like growth factor-I in vitro. Experimental Cell Research 195 53-58.

Kasperk C, Fitzsimmons R, Strong D, Mohan S, Jennings J, Wergedal J \& Bayling D 1990 Studies of the mechanism by which androgens enhance mitogenesis and differentiation in bone cells. Journal of Clinical Endocrinology and Metabolism 71 1322-1329.

Kendall SK, Saunders TL, Jin L, Lloyd RV, Glode LM, Neh TM, Keri RA, Nilson GH \& Camper SA 1991 Targeted ablation of pituitary gonadotrophs in transgenic mice. Molecular Endocrinology $\mathbf{5}$ 2025-2036.

Lauriola L, Maggiano N, Serra FG, Nori S, Tardio ML, Capelli A, Piantelli M \& Raneletti FO 1997 Immunohistochemical and in situ hybridization detection of growth hormone-producing cells in human thymoma. American Journal of Pathology 151 55-61.

Li S, Crenshaw III EB, Rawson EJ, Simmons DM, Swanson LW \& Rosenfeld MG 1990 Dwarf locus mutants lacking three pituitary cell types result from mutations in the POU-domain gene pit-1. Nature 347 528-530. 
Lima L 1988 Estudio del ritmo endógeno hipotálamo somatotropo e influencia de los niveles circulantes de esteroides sexuales sobre la secreción de GH. PhD Thesis, University of Santiago de Compostela, Spain.

Nemeskéry A, Nómeth A, Sétálo G, Vigh S \& Halász B 1976 Cell differentiation of the fetal rat anterior pituitary in vitro. Cell Tissue Research $170263-273$.

Oliver C 1980 Isolation and maintenance of differentiated exocrine gland acinar cells in vitro. In vitro 16 297-305.

Patterson PH \& Chun LLY 1977 Induction of acetylcholine synthesis in primary cultures of dissociated rat sympathetic neurones. I. Effects of conditioned medium. Developmental Biology 56 263-280.

Pierce JG \& Parsons TF 1981 Glycoprotein hormones: structure and functions. Annual Review of Biochemistry 50 465-495.

Potter DD, Landis SC, Matsumoto SG \& Furshpan EJ 1986 Synaptic functions in rat sympathetic neurones in microculture. II. Adrenergic/cholinergic dual status and plasticity. Journal of Neuroscience 6 1080-1098.

Prasad KN, Edwards-Prasad J, Carvalho E, La Rosa FG, Balbinder E, Meyers A \& Quissell D 1992 Establishment of primary cultures of rat and human parotid epithelial cells for transfection experiments. In Vitro Cell Developmental Biology 28A 493-499.

Sabatini LM, Allen-Hoffmann BL, Warner TF \& Azen EA 1991 Serial cultivation of epithelial cells from human and macaque salivary glands. In Vitro Cell Developmental Biology 27A 939-948.

Sanno N, Teramoto A, Matsuno A \& Osamura Y 1996 Expression of human pit-l product in the human pituitary and pituitary adenomas. Archives of Pathology Laboratory Medicine 120 73-77.

Shirasawa N, Shiino M, Shimizu H, Nogami H \& Ishii S 1996 Inmunoreactive luteinizing hormone (ir-LH) cells in the lung and stomach of chick embryos. Cell Tissue Research 283 19-27.
Simmons DM, Voss JW \& Ingraham HA 1990 Pituitary cell phenotypes involve cell-specific pit-l mRNA translation and synergistic interactions with other classes of transcription factors. Genes Development 4 695-711.

Spira O, Atzmon R, Rahamin E, Bar-Shavit R, Gross J, Gordon A \& Vlodausky T 1988 Striated muscle fibers differentiate in primary cultures of adult anterior pituitary cells. Endocrinology 122 3002-3004.

Tilemans D, Andries M \& Denef C 1991 Luteinizing hormone-releasing hormone and neuropeptide $\mathrm{Y}$ influence deoxyribonucleic acid replication in three anterior pituitary cell types. Evidence for mediation by growth factors released from gonadotrophs. Endocrinology 130 882-894.

Tresguerres JAF \& Esquifino A 1981 Dissociation in LH and FSH regulation in a hyperprolactinaemic rat model. Journal of Endocrinology 90 41-51.

Tresguerres JAF \& Esquifino A 1983 Posibles mecanismos de interacción entre gonadotropinas y prolactina en un modelo de hiperprolactinemia experimental. Experimental Cell Research 173 311-321.

Xu X \& Bjorntorp P 1987 Effects of sex steroid hormones on differentiation of adipose precursor cells in primary culture. Experimental Cell Research 173 311-321.

Yeh KY, Yeh M \& Holt PR 1989 Induction of intestinal differentiation by systemic and not by luminal corticosterone in adrenalectomized rat pups. Endocrinology 124 1898-1904.

Received 29 June 1998

Accepted 25 August 1998 